\section{Pattern recognition receptors in microbial keratitis}

M-A Taube ${ }^{1,2}$, M del Mar Cendra ${ }^{1}$, A Elsahn $^{1,2}$,

M Christodoulides ${ }^{1}$ and $\mathrm{P}$ Hossain ${ }^{1,2}$

\begin{abstract}
Microbial keratitis is a significant cause of global visual impairment and blindness. Corneal infection can be caused by a wide variety of pathogens, each of which exhibits a range of mechanisms by which the immune system is activated. The complexity of the immune response to corneal infection is only now beginning to be elucidated. Crucial to the cornea's defences are the pattern-recognition receptors: Toll-like and Nod-like receptors and the subsequent activation of inflammatory pathways. These inflammatory pathways include the inflammasome and can lead to significant tissue destruction and corneal damage, with the potential for resultant blindness. Understanding the immune mechanisms behind this tissue destruction may enable improved identification of therapeutic targets to aid development of more specific therapies for reducing corneal damage in infectious keratitis. This review summarises current knowledge of pattern-recognition receptors and their downstream pathways in response to the major keratitis-causing organisms and alludes to potential therapeutic approaches that could alleviate corneal blindness.
\end{abstract}

Eye (2015) 29, 1399-1415; doi:10.1038/eye.2015.118; published online 10 July 2015

\section{Introduction}

Corneal disease is a significant and often underreported problem. The most recent World Health Organization (WHO) update estimates that $1 \%$ of global visual impairment is due to corneal infection or inflammation. ${ }^{1}$ Of those reported as blind, corneal opacities contribute to $4 \%$, making it the joint fourth most common cause of blindness worldwide; the main aetiological factor is infectious keratitis. In some parts of the world, corneal blindness can be caused by keratitis in as many as $20 \%$ of adults and $40 \%$ of children. ${ }^{2}$ Trauma caused by agrarian activity is a major factor in its development. Infectious keratitis in the UK results in $\sim 4000$ people annually needing hospital treatment ${ }^{3}$ and studies in the US have shown a rise in cases associated with increasing contact lens wear. ${ }^{4,5}$ Particularly important is the fact that in both higher and lower income countries corneal disease frequently affects people of working age, causing significant associated morbidity and visual impairment. ${ }^{2,6}$ In most parts of the world bacteria are the leading pathogens and despite the use of antibiotics, irreversible corneal damage still occurs.

Visual impairment in infectious keratitis results as a consequence of (i) the interactions of the pathogen with the host tissue, (ii) the host innate inflammatory response, and (iii) the therapeutic drugs used to treat the infection. The strength of this inflammatory response and its associated damage can vary depending on the pathogen and the severity of infection. Attempts are being made to better understand the mechanisms behind pathogen recognition and host innate immune responses with the aim of identifying future targets for immunomodulatory therapies. If targeted therapies can be achieved, the inflammatory damage and loss of vision currently caused by corneal infection and its treatment could be reduced, with an associated improvement in visual outcomes and reduction in morbidity.

Pattern recognition of pathogens in the cornea

\section{Corneal barriers against infection}

The intact corneal epithelium is a formidable barrier to bacterial penetration into deeper layers. ${ }^{7}$ This is partly due to the tight junctions between superficial cells and also partly due to antibacterial peptides and innate immune signalling. ${ }^{8-12}$ In addition, bathing tear fluid contains mucins, secretory immunoglobulin A (sIgA), and surfactant protein $\mathrm{D}$, all
${ }^{1}$ Division of Clinical and Experimental Sciences, Faculty of Medicine, University of Southampton, Southampton, UK

${ }^{2}$ University Hospital Southampton NHS Foundation Trust, Southampton, UK

Correspondence: P Hossain, Eye Unit, Southampton General Hospital, Tremona Road, Southampton SO16 6YD, UK

Tel: +44 (0)23 8120 4270;

Fax: +44 (0)23 81204436 .

E-mail: parwez@soton.ac.uk

Received: 18 September 2014

Accepted in revised form:

31 May 2015

Published online:

10 July 2015 
antimicrobial factors that can bind microbes and potentially alter their interactions with corneal epithelial cells. ${ }^{13-15}$ Epithelial cells also express several antimicrobial peptides, including human $\beta$-defensin 2 (hBD-2), cathelicidin LL-37,11,12,16,17 and cytokeratin 6A. ${ }^{18}$ In addition, superficial epithelial cells can internalise bacteria and then desquamate, thereby reducing the infective load. ${ }^{19}$ Despite these defences, if microorganisms succeed in traversing the multilayered corneal epithelium, the epithelial basement membrane still presents a formidable barrier to further penetration. This is due to physical filtration via its pores that are smaller than the size of most bacteria, ${ }^{20}$ or by improving the barrier function of the epithelial cells growing on top of them. ${ }^{21}$

Penetration of bacteria to the stroma typically requires a breach in the corneal epithelium, either by mechanical trauma such as epithelial abrasions, or by intrastromal inoculation, as happens in animal models of microbial keratitis, in which pathogens are either inoculated onto a scarified corneal surface or injected intrastromally. ${ }^{22}$ Similar mechanisms may also be involved in fungal and protozoan infections. In some cases of extended contact lens wear however, infection and penetration can happen without an epithelial breach. This might be due to biofilm formation on the contact lens surfaces where residing bacteria are exposed only to sublethal concentrations of host antimicrobials and other defence factors, thereby enabling bacteria to adapt and overcome them. ${ }^{7}$

Corneal epithelial barriers to infection therefore consist of defences against adhesion and traversal. This likely involves junctional complexes, secreted and internal antimicrobial peptides, mucins, and the basal lamina foundation that provides a physical barrier while also supporting epithelial homeostasis. During and after microbial challenge, corneal epithelial defences are enhanced and regulated by epithelial derived cytokines and chemokines that can facilitate communication with cells of the immune system to further enhance corneal defences.

\section{Innate immune cells in the mammalian cornea}

A wide range of pathogenic organisms can infect the cornea, with varying mechanisms of infection and virulence (see Table 1). Although under normal circumstances the eye exhibits a certain amount of immune privilege, the cornea nonetheless must have a means of detecting and combating these pathogens.

Recent work has identified that immune cells including macrophages and dendritic cells have key roles in detecting and initiating the innate immune response in the cornea, expressing pattern-recognition receptors (PRRs) such as Toll-like receptors (TLRs) and NOD-like receptors (nucleotide-binding oligomerisation domains; NLRs). PRRs recognise invariant pathogen structures known as pathogen-associated molecular patterns (PAMPs). TLRs were discovered in human immune cell lines in the late $1990 \mathrm{~s}^{38}$ and it was noted that activation of these receptors in humans produced a cascade of inflammatory cytokines such as IL-1, IL-6, and IL-8 via NF-kB. To date, 10 of these TLR molecules have been identified in humans, each of them recognising specifically conserved regions of pathogens or their products. Recognition of these conserved domains induces a signalling pathway resulting in a proinflammatory response, with resultant tissue damage and the potential for sight loss. Table 2 summarises the major domains that are recognised by each member of the TLR family. NLRs are discussed in the context of inflammasomes below.

Early attempts to identify the presence of myeloidderived cells in the cornea concluded that Langerhans cells (LCs) were present in the peripheral third of the human corneal epithelium ${ }^{43-45}$ but that antigenpresenting cells and other bone marrow-derived lineages were largely absent from the central cornea. This led to the belief that the cornea was an immune-privileged structure, such that when its regulatory mechanisms appeared to break down it was thought to be due to external factors such as corneal grafting. ${ }^{46-48}$ However, resident corneal macrophage populations have been observed in murine and human cornea. ${ }^{47,49,50}$ A picture now emerges of a stratified resident myeloid population in the human cornea, with major histocompatibility complex (MHC) $\mathrm{II}^{+} / \mathrm{CD} 45^{+}$bone marrow-derived cells present throughout all layers of the peripheral stroma, as well as in the anterior stroma of the central cornea. ${ }^{51}$ Classification of cell surface markers has enabled cell lineage identification: myeloid-derived dendritic cells (DCs) are considered CD11c ${ }^{+}$, while monocyte-derived lineages, including LCs, are $\mathrm{CD} 14^{+} .52$

Hamrah et al ${ }^{53}$ observed that some murine DCs in the periphery of the anterior stroma also express MHC II, CD80, and CD86, but the DCs located in the centre present an immature, $\mathrm{MHC} \mathrm{II}^{-} \mathrm{CD} 80^{-} \mathrm{CD} 86^{-}$phenotype until inflammation is induced. Work by Knickelbein et a ${ }^{49}$ in humans has identified that $\mathrm{CD}_{11 \mathrm{c}^{+}} \mathrm{DCs}$ are present in the basal epithelium and anterior peripheral stroma. LCs appear to be predominantly confined to the basal epithelial layer of the peripheral cornea with a very few cells present in the peripheral stroma. Macrophages have been found to be largely present in the anterior stroma. The presence of these bone marrow-derived cells in the cornea has proved crucial to elucidating the immune response of the cornea to infection. 
Table 1 Pathogens causing corneal disease. Pathogens within each class of microorganism are listed in descending order of prevalence ${ }^{23-37}$

\begin{tabular}{|c|c|c|}
\hline Bacterial & Gram-positive & Gram-negative \\
\hline & $\begin{array}{l}\text { Staphylococcus spp (aureus, epidermidis) } \\
\text { Streptococcus pneumoniae } \\
\text { Streptococcus pyogenes } \\
\text { Streptococcus viridans } \\
\text { Corynbacterium diphtheroides } \\
\text { Nocardia spp } \\
\text { Propionibacteria acnes } \\
\text { Bacillus spp } \\
\text { Mycobacterium spp } \\
\text { Micrococcus spp }\end{array}$ & $\begin{array}{l}\text { Pseudomonas aeruginosa } \\
\text { Moraxella spp } \\
\text { Klebsiella pneumoniae } \\
\text { Enterobacter aerogenes } \\
\text { Serratia spp (marcescens, liquefaciens) } \\
\text { Acinetobacter spp } \\
\text { Enterococcus spp } \\
\text { Burkholderia cepacia } \\
\text { Escherichia coli } \\
\text { Stenotrophomonas maltophilia } \\
\text { Neisseria gonorrhoeae } \\
\text { Haemophilus spp } \\
\text { Kingella kingae } \\
\text { Pseudomonas spp (non-aeruginosa) } \\
\text { Citrobacter spp } \\
\text { Aeromonas spp }\end{array}$ \\
\hline
\end{tabular}

Chlamydial

Fungal

Viral

Parasitic

Nematodal
C trachomatis, psittaci

Fusarium spp

Aspergillus spp (flavus, fumigatus, niger, terreus and nidulans)

Alternaria spp

Cuvularia spp

Lasiodiplodia theobromae

Paecilomyces spp

Penicillium spp

Scedosporium apiospermum

Cephaliophora irregularis

Cladosporium cladosporoides

Cylindrocarpon spp

Exserohilum rostratum

Bipolaris spp

Candida spp

Pythium insidiosum

Herpes simplex virus type 1

Varicella zoster virus

Human adenovirus (serotypes 8, 19, and 37)

Enterovirus type 70

Coxsackievirus type 24

Echovirus type 13

Poliovirus type 3

Cytomegalovirus

Acanthamoeba spp (castellani, polyphaga and culbertsoni)

Microsporidia spp

Hartmannella spp

Vahlkampfia spp

Dictyostelium polycephalum

Phthriasis palpebrarum

Oestrus ovis

Loa loa

Onchocerca volvulus 
Table 2 Summary of human TLRs and their major ligands. ${ }^{39-42}$ For full general details of TLRs and their ligands please refer to reviews ${ }^{39-41}$

\begin{tabular}{lll}
\hline Toll-like receptor & Receptor ligand(s) & Pathogen association \\
\hline TLR1 associates with TLR2 & Triacyl lipopeptides & Bacteria \\
TLR2 & Lipoprotein & Predominantly Gram - ve bacteria, fungi \\
& Zymosan & Fungi \\
& Peptidoglycan & Gram +ve bacteria \\
& Lipoteichoic acid & Gram +ve bacteria \\
TLR3 & Porins & Neisseria spp. \\
TLR4 & Double-stranded RNA & Viruses \\
TLR5 & LPS bacteria \\
TLR6 associates with TLR2 to aid & Flagellin & Gram -ve bacteria \\
discrimination between diacyl and triacyl lipopeptides & Diacyl lipopeptides & Mycoplasma spp. \\
TLR7 & Single-stranded RNA & Viruses may have a role in immune \\
& & response to cancer \\
TLR8 & Poly-G oligonucleotides & Viruses \\
TLR9 & Single-stranded RNA & Bacteria \\
& Unmethylated CpG-DNA & \\
TLR10 & Currently remains unknown & \\
\hline
\end{tabular}

\section{Intracellular Nod-like receptors and inflammasome activation after pathogen recognition}

The concept of the inflammasome was coined in $2002^{54}$ and rapidly generated intense study, adding a new dimension to scientific understanding of inflammation and innate immunity. NLRs are intracellular PRRs expressed within immune cells that sense invading microorganisms and initiate the innate immune response. Phylogenetic studies propose three NLR subfamilies based on a structural nucleotide-binding domain present in these receptors: (1) the NOD (nucleotide-binding oligomerisation domain); (2) the NLRP (pyrin domain; PYD); and (3) the NLRC (caspase-associated recruitment domain, CARD), also known as IPAF. ${ }^{55}$

In response to intracellular PAMPs, some NLRs induce the assembly of multiprotein complexes named inflammasomes that serve as platforms for caspase activation and, consequently, maturation of the pro-inflammatory mediators IL-1ß and IL-18. This inflammatory response is called pyroptosis. The multiprotein scaffold is commonly described as either a 'canonical' or a 'non-canonical' inflammasome. The canonical inflammasome describes the inflammasome platform containing NLRP3, the ASC adaptor protein required to recruit the pro-caspase-1 (CASP1), and the caspases 1 or 11. The canonical inflammasome is the most studied and well characterized. A non-canonical inflammasome is used to refer to any other inflammasome complex containing molecules other than those mentioned above. ${ }^{55-57}$
To date, two inflammasomes have been identified as assembling on the corneal surface in response to an infectious agent: the NLRP3 and NLRC4 inflammasomes. In contrast to NLRC4, the canonical NLRP3 is not constitutively expressed within the cell and requires TLR activation to induce its transcription via the NF-kB pathway. ${ }^{58}$ The stimulation of NLRP3 and NLRC4 inflammasomes leads to the activation of caspase-1, a cysteine protease responsible for the cleavage and release of pro-IL-18 and pro-IL-1 $\beta$. NLRC4 requires accessory proteins called Naips for its stimulation, but does not require recruitment of the ASC molecule for caspase-1 activation. However, association with ASC enhances the assembly of the inflammasome and maturation of the pro-inflammatory cytokines..$^{59,60}$ NLRC4 is also able to activate caspase-11 for pro-IL-18 and pro-IL-1 $\beta$ processing. ${ }^{61}$ In addition, Meunier et al ${ }^{62}$ recently described the requirement for small GTPases known as guanylate-binding proteins to be present for the complete stimulation of caspase-11. Figure 1. illustrates the major components of the inflammasome pathway.

Aspergillus fumigatus, a fungal mould, is known to stimulate the NLRP3 inflammasome and to induce maturation of pro-IL-1 $\beta$ to IL- $1 \beta,{ }^{63}$ and both NLRP3 and IL-1 $\beta$ expression were found to be increased in humans suffering from fungal keratitis infection. ${ }^{64}$ Pseudomonas aeruginosa in mice is able to activate the NLRC4 inflammasome via immune cell internalisation of its bacterial flagellin, as well as via components of its type 3 secretion system. ${ }^{65}$ Streptococcus pneumoniae 


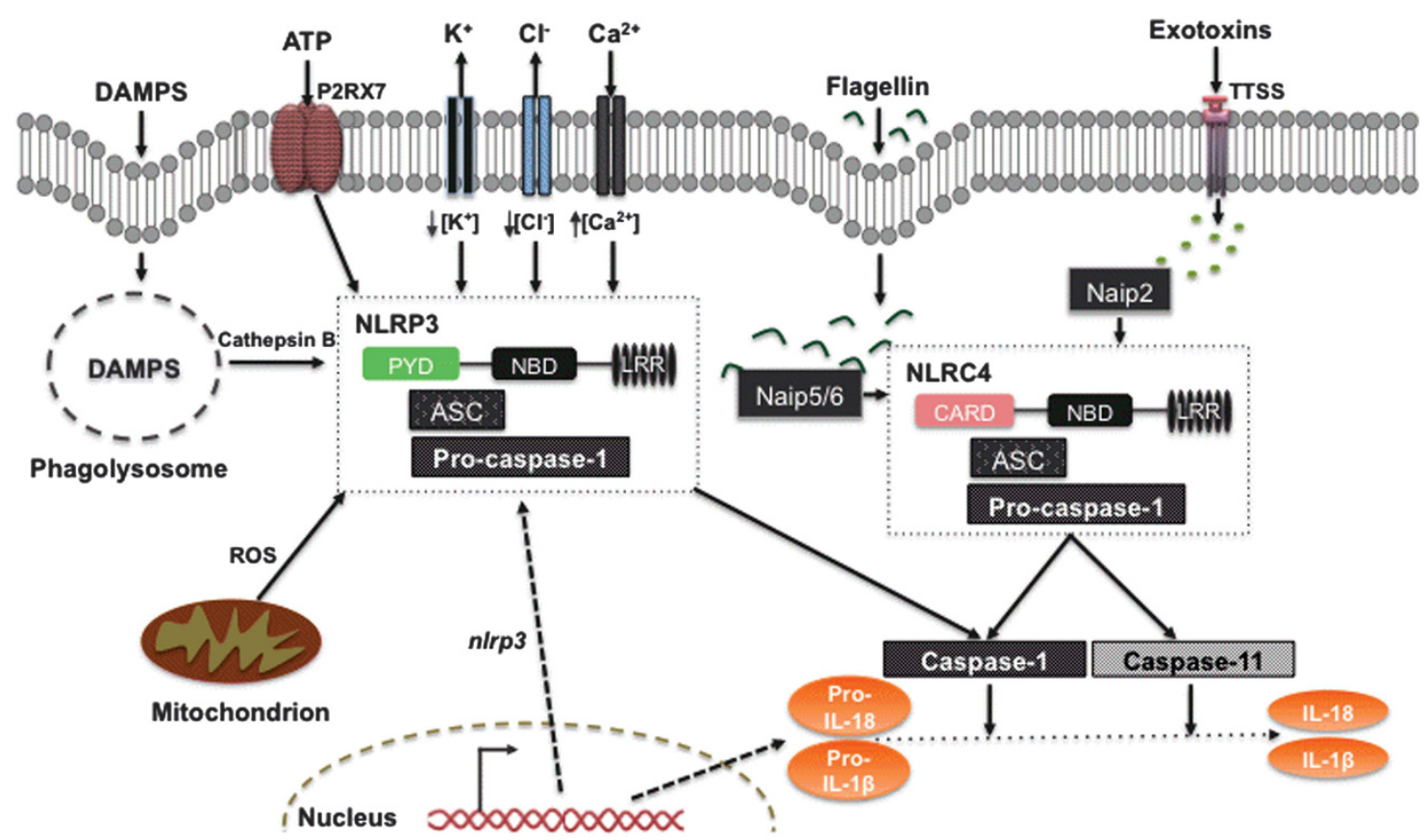

Figure 1 Assembly and activation of the inflammasome. NLRP3 and NLRC4 are the two inflammasomes described to date that assemble at the corneal surface in response to infectious agents. TLR4 stimulation induces Nlrp3 gene expression and NLRP3 transcription; in contrast, NLRC4 is constitutively expressed in the cell. ${ }^{58}$ Both inflammasomes share common structural domains (nucleotide-binding domain and LRR) and the ability to recruit the adaptor molecule ASC, which facilitates the association of pro-caspase-1. ${ }^{56}$ Different mechanisms of activation have been described for each inflammasome: extracellular ATP activates NLRP3 via P2RX7 receptor stimulation that provokes a decrease of the intracellular $\mathrm{K}^{+}$levels. ${ }^{68}$ Alteration of $\mathrm{Cl}^{-}$or $\mathrm{Ca}^{2+}$ fluxes or production of reactive oxygen species by mitochondria (a consequence of cell damage), are also able to stimulate the NLRP3 inflammasome. Furthermore, phagocytosis of damage-associated molecular pattern molecules promotes lysosome destabilization and the release of cathepsin B protein into the cytosol, activating the canonical inflammasome. ${ }^{69,70}$ NLRC4 is activated via internalisation of flagellin and components of the Pseudomonas bacterial virulence factor type 3 secretion system. ${ }^{65}$ NLRC 4 needs a protein known as Naip for its stimulation: Naip5-6 proteins are responsible for binding the internalised flagellin and Naip2 binds the components of the type 3 secretion system..$^{5,57,59}$ These inflammasomes lead to the activation of Caspase- 1 protease. Caspase- 1 protease is required to cleave the pro-interleukins necessary to generate the mature forms of IL- 18 and IL- $1 \beta$. The cysteine protease Caspase- 11 can be also activated by NLRC4 and promote the maturation of these pro-interleukins. ${ }^{61}$

pneumolysin has been shown to activate NLRP3 in mice ${ }^{66}$ and both $S$. pneumoniae and P. aeruginosa corneal infection caused upregulated expression of NLRP3 and NLRC4 in human keratitis. ${ }^{67}$ The significance of the inflammasome and stimulation of pyroptosis in corneal infection appears therefore to be a considerable contributory factor to tissue destruction and impairment of vision.

\section{Pathogens causing corneal disease}

\section{Pattern recognition mechanisms activated by microbial pathogens in the cornea}

Pseudomonas aeruginosa The healthy human cornea is inherently resistant to infection. This is attributable to multiple integrated factors that have evolved across species to protect the eye against a broad range of microbial pathogens, including bacteria, fungi, viruses and protozoa. ${ }^{7}$

$P$. aeruginosa is the most common cause of Gramnegative bacterial keratitis ${ }^{29,71}$ with a more severe clinical course than other bacterial pathogens if left untreated. ${ }^{72}$ The healthy eye is generally protected against P. aeruginosa infection. Although cultured corneal epithelial cells are easily invaded and killed by most clinical and laboratory isolates of $P$. aeruginosa, ${ }^{19,73}$ extremely large inoculates of invasive and cytotoxic $P$. aeruginosa onto intact mouse or rat corneas in vivo results in rapid bacterial clearance from the ocular surface without pathology. ${ }^{74}$ This suggests that certain defence mechanisms against infection exist in the healthy eye that are absent from laboratory culture conditions. Although many $P$. aeruginosa strains grow readily in undiluted tear fluid despite its antimicrobial components such as lactoferrin and lysozyme, ${ }^{75,76}$ tear fluid can still protect corneal epithelial cells against them. ${ }^{77,78}$ This is thought to be due to the tear fluid acting directly upon corneal epithelial cells to make them more resistant to $P$. aeruginosa invasion and cytotoxicity. ${ }^{74}$

Should conditions enable $P$. aeruginosa to breach the corneal epithelium, its lipopolysaccharide (LPS) and 
flagellin molecules are recognised by TLR4 and TLR 5 on macrophages of the corneal stroma, ${ }^{79}$ initiating a proinflammatory pathway via the well-characterised adaptor molecule MyD88. MyD88 appears to be essential to all TLR signalling except TLR3. ${ }^{80}$

Another adaptor molecule used by TLR4 is TIRAP (also known as Mal); although this is activated in $P$. aeruginosa infection, it does not appear to mediate in vivo keratitis. ${ }^{79}$ TLR4 must be associated with co-stimulatory molecule MD-2 to recognise LPS; ${ }^{81}$ accessory proteins lipopolysaccharide-binding protein and CD14 transfer the LPS molecules from the bacteria to the TLR4/MD-2 complex. ${ }^{82}$ Resident myeloid cells are capable of conferring LPS responsiveness, ${ }^{83}$ but although TLR4 is also expressed on human corneal epithelial cells, MD-2 is not detectable. It is thought that MD-2 expression is enabled by the infiltration of immune cells such as natural killer cells, which activate the JAK2/STAT1 transcription pathway and produce IFN- $\gamma .84,85$ In a murine model of corneal inflammation, Chinnery et al ${ }^{83}$ demonstrated that TLR4 activation on resident corneal macrophages and DCs stimulated macrophage and neutrophil recruitment and induced corneal haze.
On activation, numerous adaptor proteins are recruited to initiate the inflammatory response (see Figure 2). In addition to the MyD88 pathway, a non-MyD88 pathway via TRIF exists which has also been found to be present in P. aeruginosa keratitis. ${ }^{83}$ MyD88/TRIF pathways induce production of a chemokine known as CXCL1/KC which recruits neutrophils to the cornea from limbal blood vessels. MyD88/TRIF pathways also promote the production of IL- $1 \alpha$ and IL- $1 \beta$, which creates a positive feedback loop via the interleukin 1 receptor IL-1R1 interaction with MyD88. ${ }^{79}$ The presence of TLR4 in murine corneal $P$. aeruginosa infection has also been associated with the release of antimicrobial factors such as nitric oxide (NO), the product of inducible nitric oxide synthase (iNOS) and $\beta$-defensin $2 .{ }^{86}$

\section{Staphylococcus aureus Although studies consistently} report Staphylococcus spp. as some of the commonest causes of bacterial keratitis, ${ }^{90-92}$ contact with the organisms infrequently results in infection. A study by Moreau et al, ${ }^{93}$ in which $S$. aureus was topically applied to scarified rabbit eyes resulted in bacterial killing and identified a role for phospholipase $\mathrm{A} 2$ in the tear film as

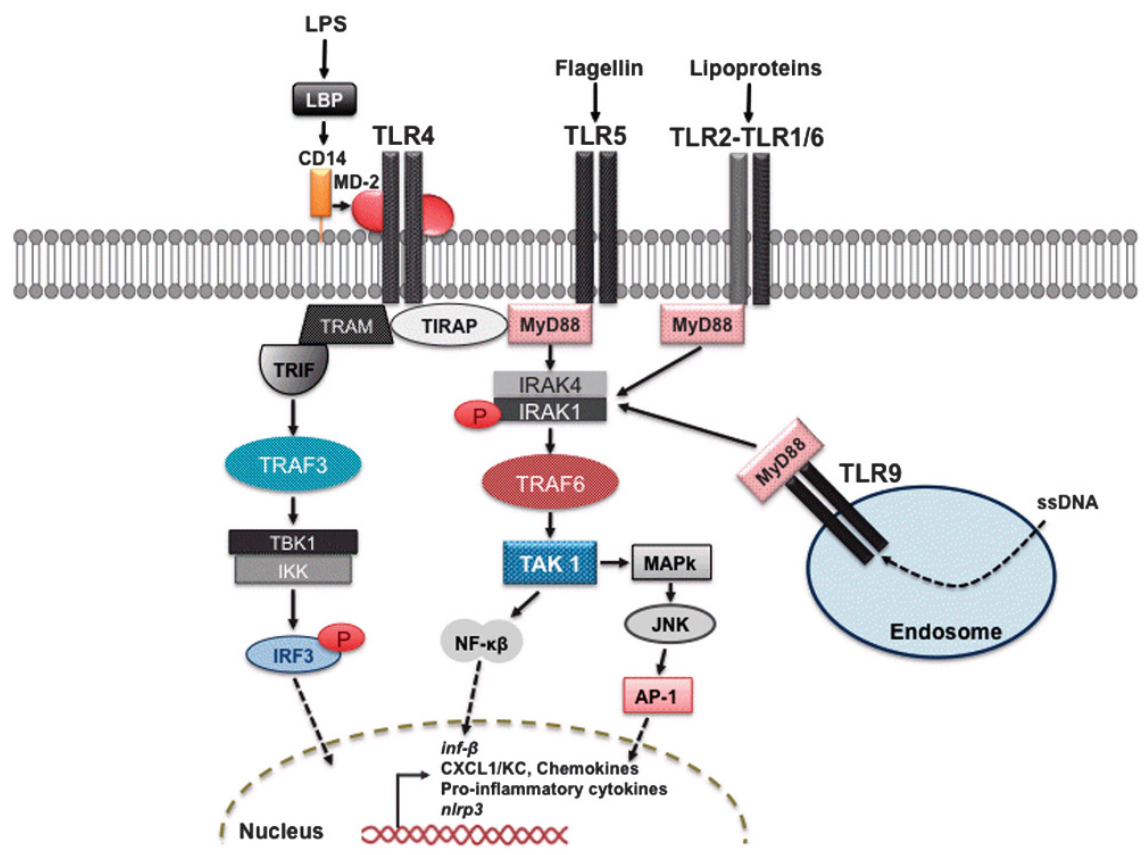

Figure 2 Immune recognition of Pseudomonas aeruginosa molecular patterns. LPS-binding protein binds the LPS from the P. aeruginosa cell wall and the complex is recognised by the CD14 receptor. CD14 transfers the LPS to the MD-2 molecule that is associated with TLR4. MD-2 undergoes changes in its conformation and triggers the stimulation of TLR4. TLR4 dimerises and recruits TIR-domain-containing adaptor proteins (TRIF and TIRAP) to start the signal transduction. TIRAP requires MyD88 protein for its activation, which also recruits IL-1 receptor-associated kinases IRAK4 and IRAK1. Phosphorylation of IRAK1 by IRAK4 activates the E3 ubiquitin protein ligase TNFR-associated factor 6 (TRAF6). This activates TGF- $\beta$ associated kinase (TAK) 1 which results in transcription of pro-inflammatory cytokines via the NF-kB and mitogen-activated (MAP) kinase/JNK pathways. TLR3 can also signal via TRIF..$^{87}$ Activation of TLR3/4 recruits TRIF via TRAM which signals through RIP1 and TRAF6 to the NF-kB and JNK pathways. TRIF also activates TRAF3, which through TBK1 and IKK phosphorylates IRF3 and stimulates the production of type I interferons. ${ }^{80,88,89}$ ssDNA containing unmethylated CpG motifs is sensed by TLR9. In contrast to the other TLRs mentioned above, TLR9 is localised in the endosome. It also activates the MyD88-dependent pathway. ${ }^{39,41}$ 
a crucial bactericidal agent. Interestingly, work by Heimer et $a l^{94}$ suggests that on infection of human corneal epithelial cells in vitro the principal difference between toxigenic and non-toxigenic strains of $S$. aureus appears to be an increased activation of stress response molecules such as heat shock proteins on exposure to a toxigenic strain of $S$. aureus.

Recognition of $S$. aureus at the corneal surface has been shown to be mediated by TLR2. ${ }^{95,96}$ At least three different PAMPs have been identified as binding to TLR2 and activating the immune response in $S$. aureus keratitis: bacterial lipoproteins, ${ }^{95}$ peptidoglycan molecules, ${ }^{97}$ and S. aureus protein A (SpA). ${ }^{98}$ TLR2 then activates the MyD88 pathway; ${ }^{95}$ however, Kumar et al ${ }^{98}$ demonstrated that SpA also activated other pathways (p38 and ERK) via an unknown receptor, citing TNF- $\alpha$ receptor 1 (TNFR1) as a potential candidate. The work of Heimer et al ${ }^{94}$ lends further support to this theory: a large increase in the dendritic cell chemokine CCL20 was identified when human corneal epithelial cells were stimulated with both toxigenic and non-toxigenic strains of $S$. aureus, which appeared to be independent of TLR2 stimulation.

Bacterial lipoproteins have also been shown to activate alternative pathways to MyD88, including p38 and ERK but also JNK. This results in release of pro-inflammatory mediators and chemotactic cytokines such as IL-6, IL-8, and ICAM-1 as well as antibacterial molecules such as NO. ${ }^{95}$ Peptidoglycan was shown to activate all four of the pathways described above; ${ }^{97}$ this study also identified release of human $\beta$-defensin 2 by the epithelial cells, the same group later confirming its release via pathways downstream of TLR2. ${ }^{99}$ A study by Adhikary et al ${ }^{100}$ described the JNK pathway as predominant in TLR2 activation.

Onchocerca volvulus (onchocerciasis) Onchocerciasis is due to infection with the microfilarial nematode worm Onchocerca volvulus, which can produce a blinding keratitis. Systemic response to O. volvulus has been shown to vary based on differing immunological profiles, with some infected individuals displaying no symptoms, while others develop a severe dermatitis known as sowda. ${ }^{101,102}$ Studies in animals suggest that previous exposure to $O$. volvulus antigens is necessary to develop systemic symptoms, indicating a role for the adaptive immune response. ${ }^{103,104} \mathrm{~A}$ strong Th2 response has been implicated, with release of IL-4, IL-5, IFN- $\gamma, \operatorname{IgG}_{1}$, and $\operatorname{IgE}{ }^{105-107}$

More recently, attention has focused on the fact that O. volvulus maintains an endosymbiotic relationship with Wolbachia bacteria and that microfilaria release bacterial products which activate the immune response in human embryonic kidney cells and mice. ${ }^{108,109}$ Microfilaria can invade the eye and stimulate both innate and adaptive immunity. Recognition of Wolbachia products on macrophages and DCs is mediated by TLR2/TLR6, leading to MyD88/TIRAP activation and the release of pro-inflammatory cytokines via NF-kB. ${ }^{110}$ Previous work suggests that Th2 immune responses predominate (see Pearlman and Hall ${ }^{111}$ for review), but Turner et al ${ }^{112}$ showed that activated CD11 $c^{+}$DCs upregulate CD80 and CD86 adhesion molecules and can stimulate a CD4 ${ }^{+} \mathrm{T}$-cell activation with a predominantly Th1 response. Interestingly, this study also demonstrated that Wolbachia depletion resulted in a switch to a Th2-driven inflammatory response.

Once activated, macrophages release further Th1-driving cytokines such as IL-12 and TNF- $\alpha{ }^{109,111}$ Neutrophils are recruited from the limbal vessels via release of CXC chemokines such as CXCL1 and CXCL2 and upregulation of vascular adhesion molecules such as PECAM-1.113,114 Eosinophil infiltration occurs later in the disease but aggravates the inflammatory response. ${ }^{106,114-116}$ However, neutrophil involvement is thought to be the driving factor behind the progressive corneal haze seen in onchocerciasis. ${ }^{116}$

Fungi The most common agents in fungal infection are Fusarium spp. and Aspergillus spp. ${ }^{117}$ Compared with bacterial keratitis, fungal keratitis is frequently associated with poorer outcomes ${ }^{118}$ and is a recurrent problem in many parts of USA with a recent increase in contact lens wearers. ${ }^{119-121}$ In developing countries, ocular trauma is a major risk factor. ${ }^{31,122,123}$ Fungal spores are able to penetrate compromised epithelium where they germinate, expressing $\beta$-glucan and $\alpha$-mannan molecules on their surface. These are recognised by the receptors Dectin- 1 and Dectin-2 on macrophages, which then signal via spleen tyrosine kinase (Syk) and CARD 9 proteins to activate the NF-kB pro-inflammatory pathway. This produces IL-1 $\beta$ and chemokines such as CXCL1 and CXCL2. ${ }^{124,125}$ IL-1 $\beta$ is recognised by the IL-1R1 receptor and via MyD88 activates further pro-chemotactic cytokines and upregulation of vascular adhesion molecules to promote neutrophil recruitment. Leal et al have also demonstrated a role for TLR4 in fungal killing. ${ }^{125}$ Analysis of infected human corneas has revealed high levels of IL- $1 \beta$, IL- 8 , IL-17, and $\mathrm{TNF} \alpha$ in the early stages of fungal infection. Later stages identified $\mathrm{CD}^{+}$and $\mathrm{CD} 4^{+} \mathrm{T}$-cells, with associated high levels of IL-17 and interferon- $\gamma \cdot{ }^{126}$ A study by Taylor et al ${ }^{127}$ identified IL-17 as a cytokine involved in fungal killing; infiltration of Th1 and Th17 cells and a subpopulation of IL-17 producing neutrophils enabled optimal immune protection.

Herpes simplex virus Herpes simplex virus (HSV) is thought to be the primary global cause of infectious blindness. HSV1 is more commonly associated with oral 
and ocular pathology, while HSV2 is frequently transmitted through sexual contact. ${ }^{128}$ In addition, HSV infection presents the particular problem of recurrent infection.

HSV1 binds to host cells via membrane glycoproteins. To date, five glycoproteins have been described that mediate binding and fusion with the host cell: glycoprotein $\mathrm{C}(\mathrm{gC}), \mathrm{gB}, \mathrm{gD}, \mathrm{gH}$, and gL. Each of these has a role in the binding and adhesion process to enable the viral capsid to enter the cell. ${ }^{129-131}$ Several host surface receptors have been identified, including herpes virus entry mediator, nectin-1, 3-O-sulphated heparan sulphate and paired immunoglobulin-like type 2 receptor $\alpha$ (PILR$\alpha) .{ }^{132-135}$ However, a study by Shukla et al ${ }^{136}$ identified nectin- 1 as being the crucial mediator in a murine model of corneal infection. Of note when considering the mechanism of HSV1 infection is the fact that phylogenetic analysis suggests the evolution of at least six distinct HSV1 genogroups, with multiple recombination events detected in the genome coding for glycoproteins. ${ }^{137,138}$ The high mutation rate of such viral proteins provides an additional challenge when aiming to identify targeted and/or personalised therapeutic options.

HSV1 activates multiple immune pathways on binding with a cell. TLR2 ${ }^{-/}$mice have been shown to have a decreased inflammatory response to infection, ${ }^{139,140}$ whereas CpG sequences of HSV1 DNA are recognised stimulators of TLR9. 141,142 TLR3 recognises doublestranded RNA and has been identified as an important mediator of HSV1 infection. ${ }^{143,144}$ Human corneal epithelial cells have been shown to respond to HSV1 via TLR3 and also to express TLR7 as a result of infection. ${ }^{145}$ Additionally, TLR4 is activated in mice by endogenous heat shock protein 70 (Hsp70) and $\beta$-defensin-3 expressed by corneal cells in response to the virus. ${ }^{140}$ Interestingly, MyD88 - - mice had reduced corneal inflammation, but were unable to control viral spread, with $70 \%$ dying of presumed HSV encephalitis.

TLR9 is known to activate the NF-kB, p38 and JNK pathways. ${ }^{40}$ In addition, the transcription factors cAMP response element (CRE) and CCAAT/enhancer binding protein $(\mathrm{C} / \mathrm{EBP})$ are activated in the mouse corneal endothelium, leading to release of numerous proinflammatory cytokines including IL-6, RANTES/CCL5 and CXCL10. ${ }^{146}$ Ligand binding to TLR3 activates TRIF, which in turn activates NF-kB and interferon regulatory factor 3 (IRF3), an interferon regulatory factor. In addition to cytokines such as IL-6, IL-8, and TNF- $\alpha$ produced by NF-kB transcription, activation of IRF3 results in production of anti-viral cytokines such as type 1 interferons (IFN) $-\alpha$ and $-\beta .^{145,147-151}$ TLR7 signals both via MyD88 and NF-kB but also via IRF7, which causes type 1 IFN to be produced; in addition, IRF7 can interact with the MyD88 pathway via TRAF6 and IRAK4. ${ }^{152,153}$
Activation of these pathways recruits DCs, macrophages, neutrophils and NK cells to aid in clearance of the virus (see Rowe et al ${ }^{154}$ for a review of HSV keratitis, including innate immune cells and their ligands). Latency of the virus occurs due to a switch in the viral genome that suppresses lytic genes and maintains an equilibrium between latency associated transcripts (LATs) and micro RNAs that silence the active genome. ${ }^{155}$ Immune control of the virus during the latency phase is thought to exist, mediated by HSV1-specific CD8 ${ }^{+}$T-cells capable of releasing IFN $-\gamma \cdot{ }^{156}$ Although the causes and mechanisms for reactivation are beyond the scope of this review, several differences between primary infection and recurrent disease are known to exist. Despite the fact that IL-6 is an important pro-inflammatory cytokine in primary disease, it has been shown to be of little significance in reactivation, in contrast to CXCL1 which acts as a chemokine to attract neutrophils to the site of infection. ${ }^{157} \mathrm{CD}^{+}$and $\mathrm{CD}{ }^{+}$T-cells are important mediators in recurrent disease, ${ }^{158}$ while other factors such as the chemokines CCL2 and CCL3 appear to have their roles reversed in reactivation, with CCL2 increasing disease severity and CCL3 appearing to offer some protection. ${ }^{159}$ However, full details of the differences between primary and recurrent infection remain to be elucidated.

Acanthamoeba Acanthamoeba is a ubiquitous protozoan pathogen capable of causing severe and persistent corneal infection. It exists in active trophozoite form but can also encyst, creating the potential for reactivation of disease after treatment is ended. ${ }^{160}$ Several studies have concluded that infection with Acanthamoeba does not protect against reinfection, suggesting that immunological defence is predominantly mediated by the innate immune system. ${ }^{161-164}$

Patients presenting with Acanthamoeba infection have been found to have low levels of anti-Acanthamoeba sIgA in their tearfilms, ${ }^{165}$ raising the suggestion that $\operatorname{IgA}$ is an important protective factor against infection at the corneal surface. Various protective mechanisms of IgA have been identified, including inhibition of Acanthamoeba binding to epithelial cells, 161,166 complement activation and opsonisation ${ }^{167,168}$ and augmentation of neutrophilic killing. ${ }^{169}$

More recently, the involvement of TLRs in pathogenesis of Acanthamoeba keratitis has been characterised. Under favourable conditions, Acanthamoeba is able to attach to the cell surface via mannose-binding protein, which interacts with mannose-containing glycoproteins on the corneal surface. ${ }^{170,171}$ The trophozoite then releases a mannose-induced serine protease (MIP-133) which causes cytolysis of corneal epithelial cells and enables the Acanthamoeba to infiltrate the deeper layers of corneal 
tissue. ${ }^{172,173}$ Acanthamoeba is recognised by TLR4, which initiates the MyD88/NF-kB pathway and also the MAPK/ERK pathway, leading to release of proinflammatory and chemotactic mediators such as IL-8, CXCL2, TNF- $\alpha$, and IFN- $\beta .{ }^{174,175}$

Macrophage activation in the presence of antiAcanthamoeba antibody and IFN- $\gamma$ has been shown to demonstrate trophozoite killing activity. ${ }^{167,176}$ Macrophages are thought to be a crucial mediator in early infection: depletion of macrophages in a Chinese hamster model of Acanthamoeba keratitis produced a notable worsening of disease. ${ }^{177}$ Neutrophils are also capable of killing trophozoites, ${ }^{169,178}$ and both neutrophils and macrophages are able to kill cysts; however, no chemotactic stimulus is recognised when cysts are dormant in the cornea. ${ }^{179}$ Steroid use in treatment of Acanthamoeba has been shown to increase the virulence of the disease, with proliferation of trophozoites and stimulation of excystment. ${ }^{180}$

An additional factor in the pathology of Acanthamoeba keratitis is its frequent co-existence in symbiotic relationships with potentially pathogenic species of bacteria. A study by Iovieno et al ${ }^{181}$ identified strains of Legionella, Pseudomonas, Chlamydia and Mycobacterium present in confirmed cases of Acanthamoeba keratitis. Where an endosymbiotic relationship was found, an increase in corneal toxicity was also noted. Moreover, the authors suggest that bacterial co-infection could delay or confound the diagnosis of Acanthamoeba, further damaging the cornea before correct treatment is initiated.

\section{The relevance of animal models of keratitis}

Much of the work that has been carried out in understanding the pathogenesis of infectious keratitis has used animal models. These provide a valuable insight into immune function in the mammalian cornea, but require complementary approaches when regarded from a clinical perspective. Animal models are limited by the fact that they are anatomically and physiologically distinct from human tissues. Examples include the fact that the blink rate in both mice and rabbits is lower than that in humans; ${ }^{182,183}$ humans also have a much higher concentration of lysozyme in their tears. ${ }^{184}$ Rabbits possess a nictitating membrane, and the structure of a human cornea is different in several ways to that of mice and rabbits: Bowman's layer and Descemet's membrane are thicker, ${ }^{185}$ the orientation of the collagen is different ${ }^{186}$ and the depth of each of the layers varies depending on species. ${ }^{187}$

On a molecular level, examples of species differences include the fact that mice are known to use several NAIP accessory proteins to activate the NLRP4 inflammasome, whereas in humans only one type of NAIP has been found. ${ }^{59,188}$ Caspase- 11 is known to be present in mice, but its analogue in humans is caspase- $4 .{ }^{189}$ Differences in cytokines also exist, such as MIP-2 in mice which is equivalent to human IL-8. ${ }^{190}$ In addition, the surface mucins of humans are structurally different to those of other mammals. ${ }^{191}$ Moreover, the methods used to cause keratitis in animal models do not always mimic the natural infective process. Intrastromal injection is frequently used that bypasses the cell surface stage of infection; ${ }^{192-195}$ other methods include removal of the corneal epithelium, ${ }^{196}$ corneal scratch ${ }^{197}$ or applying contact lenses coated in bacteria to wounded corneas. ${ }^{198}$

Generally, the differences between animal and human anatomy and immunology suggest that a cautious approach is necessary when interpreting findings from animal studies in a clinical perspective. The development of primary human cell/explant models would bring us closer to revealing the true nature of pathogen-host cell interactions in microbial keratitis.

\section{Potential targeted molecular therapies}

Studying immune pathways and mechanisms of infectious keratitis could identify new therapeutic targets to ameliorate disease and reduce tissue damage. At present, clinical use of topical steroids is frequently relied upon, but this is a non-specific attempt to reduce inflammation and can be associated with complications such as corneal thinning and perforation, increased intra-ocular pressure and poorer outcomes in infections such as Nocardia, HSV1, and Acanthamoeba keratitis. ${ }^{180,199,200}$ The Steroids for Corneal Ulcers Trial (SCUT) has shown in large multicentre trials that steroids have no significant benefit or harm if used adjunctively alongside treatment of bacterial keratitis in the short term, but appear to improve visual outcomes at 12 months post treatment. Those with the most significant improvement in visual outcomes were those whose baseline vision was poorest, with most of the improvement occurring within the first 3 months for all patients. ${ }^{199,201,202}$

In the search for more specific, tailored therapies, molecular targets are being investigated as a means of reducing tissue damage and restoring sight. Various avenues are being explored according to specific pathogen characteristics and cellular pathways. Work is continuous, but it appears that promising opportunities are being identified. Alekseev et al ${ }^{203}$ have recently identified a kinase, ataxia telangiectasia mutated (ATM) kinase, whose inhibition reduces the severity of keratitis in a mouse model of HSV1 keratitis and additionally slows viral replication in rabbit and human cultured corneas. A high-affinity human monoclonal antibody to S. aureus $\alpha$-toxin has been found to be effective at reducing corneal damage $\mathrm{e}^{204}$ and a new antibiotic, targocil, 
has had some preliminary success at inhibiting the severity of staphylococcal infections. ${ }^{205}$ Several potential therapies have been identified in Pseudomonas infection, including lithium chloride $\mathrm{e}^{206}$ and a caspase- 1 inhibitor that reduces the amount of IL- $1 \beta$ produced. ${ }^{207}$ Factors that improve corneal inflammation include the apoptotic Fas pathway which regulates the production of proinflammatory cytokines ${ }^{208}$ and a phospho-inositol-3kinase (PI3K)/Akt pathway that activates a receptor known as triggering receptor expressed on myeloid cells 2 (TREM-2). ${ }^{209}$ All of these reduce inflammation and tissue damage and may be avenues to explore further.

A novel approach has been investigated in fungal keratitis, with some success: using small interfering RNA targeted against TLR2, Guo et al ${ }^{210}$ were able to improve the outcome of $A$. fumigatus disease in a rat model, with a decreased fungal burden and reduced production of pro-inflammatory cytokines leading to clearer corneas and fewer instances of perforation. A pathway has also been identified in sterile corneal inflammation to inhibit neutrophil infiltration and macrophage activation: heat shock protein HSPB4 appears to act as a damageassociated molecular pattern, activating TLR2 and the NF-kB pathway. ${ }^{211}$ The authors showed that inhibition of this pathway via HSPB4 antibodies or TNF- $\alpha$ stimulated gene/protein 6 (TSG6) suppressed macrophage activation and resultant neutrophil infiltration, leading to an improvement in corneal clarity. Meanwhile the endosymbiotic nature of $O$. volvulus with Wolbachia bacteria has led to trials of doxycycline being used to deplete the bacteria and facilitate treatment of the worms. ${ }^{212-214}$

Corneal infiltrates in non-keratitic diseases show some promise and offer another avenue of exploration: a case report of cryopyrin associated periodic fever syndrome, in which a mutation in the NLRP3 gene causes overexpression of IL- $1 \beta$, demonstrated successful treatment outcomes with IL-1 $\beta$ monoclonal antibody kanakinumab, ${ }^{215}$ and anakira, an IL-1 antagonist, has been used successfully in corneal infiltrates. ${ }^{216}$

Currently, there is strong interest in the use of collagen cross-linking (CXL) using ultraviolet-A (UV-A) light and riboflavin is a treatment of infectious keratitis. In this procedure riboflavin is applied to the affected corneal surface and the agent acts as a photosensitizer, which generates reactive oxygen species which are activated by UV-A light. The resulting photochemical reactions are thought to result in covalent bonds to cross-link collagen fibres in the corneal stroma and thus increase the strength of the cornea. Alio et al ${ }^{217}$ performed a meta-analysis of 12 studies that used this approach against a variety of types of microbial keratitis. They analysed a total 104 eyes that were treated using a range of treatment protocols with varying levels of clinical presentation. In the majority of cases cross-linked patients were reported to have halting of the corneal melting process. Few patients developed complications from CXL therapy. The treatment appeared to show promise in in bacterial and Acanthamoeba infections but less so in fungal infections.

There were concerns that CXL could halt drug penetration for patients with fungal keratitis.

Additionally, in rabbit studies of Acanthamoeba keratitis CXL showed no beneficial effect. A major difficulty with the data from the studies so far is the wide variation in the type of infectious keratitis cases, with patients at different stages of clinical presentation treated with varying therapeutic regimens. Until more controlled studies are undertaken and reported, it is difficult to recommend CXL routinely. However, CXL in microbial keratitis does offer a reasonable rationale to halt corneal melting in selected cases. It is likely that a combined approach using PAMP inhibitor-based anti-inflammatory agents with newer antimicrobials/CXL/anti-matrix metalloproteineases will show the strongest effect in treating corneal tissue damage.

In the context of infectious keratitis the goal of individualised, targeted therapy appears to be moving closer. However, in addition to the range of molecular pathways activated, the characteristics of a bacterial keratitis may depend upon such features as bacterial virulence and toxigenicity whereas a viral keratitis may depend upon the viral genotype and rate of mutation. Factors such as these may continue to present challenges that must be taken into account when designing future therapies.

\section{Conclusion}

The importance of PAMPs has significantly increased over the past decade. We have reached an exciting point in the study of infectious keratitis, with so many molecular pathways being identified. This provides several opportunities to develop therapies targeted to modifying disease outcomes. However, more work on the various potential therapeutic targets that exist within the molecular pathways we are beginning to define must be done. Ultimately, these therapies will need to balance adequate treatment of disease with minimising tissue damage in such a thin tissue as the highly specialised cornea. This presents an ongoing challenge for both scientists and clinicians. ${ }^{218}$ Nonetheless, we may now be closer than previously imagined to effective, targeted therapies to treat corneal tissue damage and subsequent blindness as a result of the global disease that is infectious keratitis. 


\section{Conflict of interest}

The authors declare no conflict of interest.

\section{Acknowledgements}

MAT was supported by the University of Southampton National Institute of Health Research Academic Foundation Programme. MC and AE were supported by the Royal College of Surgeons of Edinburgh, the National Eye Research Centre and the British Council for the Prevention of Blindness.

\section{References}

1 Pascolini D, Mariotti SP. Global estimates of visual impairment: 2010. Br J Ophthalmol 2012; 96: 614-618.

2 Wang H, Zhang Y, Li Z, Wang T, Liu P. Prevalence and causes of corneal blindness. Clin Experiment Ophthalmol 2014; 42: 249-253.

3 Dart JKG. The epidemiology of contact lens related disease in the United Kingdom: a review. CLAO J 1993; 19: 241-246.

4 Erie JC, Nevitt MP, Hodge DO, Ballard DJ. Incidence of ulcerative keratitis in a defined population from 1950 through 1988. Arch Ophthalmol 1993; 111: 1665-1671.

5 Jeng BH, Gritz DC, Kumar AB, Holsclaw DS, Porco TC, Smith SD et al. Epidemiology of ulcerative keratitis in Northern California. Arch Ophthalmol 2010; 128: 1022-1028.

6 Cheng KH, Leung SL, Hoekman HW, Beekhuis WH, Mulder PG, Geerards AJ et al. Incidence of contact-lensassociated microbial keratitis and its related morbidity. Lancet 1999; 354: 181-185.

7 Evans DJ, Fleiszig SM. Why does the healthy cornea resist Pseudomonas aeruginosa infection? Am J Ophthalmol 2013; 155: 961-970.

8 Pearlman E, Johnson A, Adhikary G, Sun Y, Chinnery HR, Fox $\mathrm{T}$ et al. Toll-like receptors at the ocular surface. Ocul Surf 2008; 6: 108-116.

9 McDermott AM. The role of antimicrobial peptides at the ocular surface. Ophthalmic Res 2009; 41: 60-75.

10 Kumar A, Yu FS. Toll-like receptors and corneal innate immunity. Curr Mol Med 2006; 6: 327-337.

11 Kumar A, Yin J, Zhang J, Yu FS. Modulation of corneal epithelial innate immune response to Pseudomonas infection by flagellin pretreatment. Invest Ophthalmol Vis Sci 2007; 48: 4664-4670.

12 McDermott AM, Redfern RL, Zhang B, Pei Y, Huang L, Proske RJ. Defensin expression by the cornea: multiple signalling pathways mediate IL-1beta stimulation of hBD-2 expression by human corneal epithelial cells. Invest Ophthalmol Vis Sci 2003; 44: 1859-1865.

13 Fleiszig SM, Zaidi TS, Ramphal R, Pier GB. Modulation of Pseudomonas aeruginosa adherence to the corneal surface by mucus. Infect Immun 1994; 62: 1799-1804.

14 Ni M, Evans DJ, Hawgood S, Anders EM, Sack RA, Fleiszig $\mathrm{SM}$. Surfactant protein D is present in human tear fluid and the cornea and inhibits epithelial cell invasion by Pseudomonas aeruginosa. Infect Immun 2005; 73: 2147-2156.

15 Masinick SA, Montgomery CP, Montgomery PC, Hazlett LD. Secretory IgA inhibits Pseudomonas aeruginosa binding to cornea and protects against keratitis. Invest Ophthalmol Vis Sci 1997; 38: 910-918.
16 Redfern RL, Reins RY, McDermott AM. Toll-like receptor activation modulates antimicrobial peptide expression by ocular surface cells. Exp Eye Res 2011; 92: 209-220.

17 McNamara NA, Van R, Tuchin OS, Fleiszig SM. Ocular surface epithelia express mRNA for human beta defensin-2. Exp Eye Res 1999; 69: 483-490.

18 Tam C, Mun JJ, Evans DJ, Fleiszig SM. Cytokeratins mediate epithelial innate defense through their antimicrobial properties. J Clin Invest 2012; 122: 3665-3677.

19 Fleiszig SM, Zaidi TS, Pier GB. Pseudomonas aeruginosa invasion of and multiplication within corneal epithelial cells in vitro. Infect Immun 1995; 63: 4072-4077.

20 Abrams GA, Goodman SL, Nealey PF, Franco M, Murphy CJ. Nanoscale topography of the basement membrane underlying the corneal epithelium of the rhesus macaque. Cell Tissue Res 2000; 299: 39-46.

21 Alarcon I, Kwan L, Yu C, Evans DJ, Fleiszig SM. Role of the corneal epithelial basement membrane in ocular defence against Pseudomonas aeruginosa. Infect Immun 2009; 77: 3264-3271.

22 Hazlett LD. Bacterial infections of the cornea (Pseudomonas aeruginosa). Chem Immunol Allergy 2007; 92: 185-194.

23 Shah A, Sachdev A, Coggon D, Hossain P. Geographic variations in microbial keratitis: an analysis of the peerreviewed literature. Br J Ophthalmol 2011; 95: 762-767.

24 Ray KJ, Prajna L, Srinivasan M, Geetha M, Karpagam R, Glidden D et al. Fluoroquinolone treatment and susceptibility of isolates from bacterial keratitis. JAMA Ophthalmol 2013; 131: 310-313.

25 Oldenburg CE, Lalitha P, Srinivasan M, Manikandan P, Bharathi MJ, Rajaraman R et al. Moxifloxacin susceptibility mediates the relationship between causative organism and clinical outcome in bacterial keratitis. Invest Ophthalmol Vis Sci 2013; 54: 1522-1526.

26 Sengupta S, Thiruvengadakrishnan K, Ravindran RD, Vaitilingam MC. Changing referral patterns of infectious corneal ulcers to a tertiary care facility in south India-7-year analysis. Ophthalmic Epidemiol 2012; 19: 297-301.

27 Wong T, Ormonde S, Gamble G, McGhee CN. Severe infective keratitis leading to hospital admission in New Zealand. Br J Ophthalmol 2003; 87: 1103-1108.

28 Laspina F, Samudio M, Cibils D, Ta CN, Fariña N, Sanabria R et al. Epidemiological characteristics of microbiological results on patients with infectious corneal ulcers: a 13-year survey in Paraguay. Graefes Arch Clin Exp Ophthalmol 2004; 242: 204-209.

29 Otri AM, Fares U, Al-Aqaba MA, Miri A, Faraj LA, Said DG et al. Profile of sight-threatening infectious keratitis: a prospective study. Acta Ophthalmol 2013; 91: 643-651.

30 Mascarenhas J, Srinivasan M, Chen M, Rajaraman R, Ravindran M, Lalitha P et al. Differentiation of etiologic agents of bacterial keratitis from presentation characteristics. Int Ophthalmol 2012; 32: 531-538.

31 Leck AK, Thomas PA, Hagan M, Kaliamurthy J, Ackuaku E, John $\mathrm{M}$ et al. Aetiology of suppurative corneal ulcers in Ghana and South India, and epidemiology of fungal keratitis. Br J Ophthalmol 2002; 86: 1211-1215.

32 Kimura H, Saitoh M, Miyakubo H, Yoshida H, Kato M, Nagai A et al. Keratoconjunctivitis caused by echovirus type 13 in Japanese children. Pediatr Infect Dis J 2003; 22: 758-759.

33 Kasová V, John J, Koza J, Matyásová I. Poliovirus type 3 keratoconjunctivitis. J Infect Dis 1980; 142: 292.

34 Thanathanee O, Enkvetchakul O, Rangsin R, Waraasawapati S, Samerpitak K, Suwan-apichon O. 
Outbreak of Pythium keratitis during rainy season: a case series. Cornea 2013; 32: 199-204.

35 Reddy AK, Balne PK, Garg P, Sangwan VS, Das M, Krishna PV et al. Dictyostelium polycephalum infection of human cornea. Emerg Infect Dis 2010; 16: 1644-1645.

36 Sreejith RS, Reddy AK, Ganeshpuri SS, Garg P. Oestrus ovis ophthalmomyiasis with keratitis. Indian J Med Microbiol 2010; 28: 399-402.

37 Alexandrakis G, Miller D, Huang AJ. Amebic keratitis due to Vahlkampfia infection following corneal trauma. Arch Ophthalmol 1998; 116: 950-951.

38 Medzhitov R, Preston-Hurlburt P, Janeway CA. A human homologue of the Drosophila Toll protein signals activation of adaptive immunity. Nature 1997; 388: 394-397.

39 Takeda K, Kaisho T, Akira S. Toll-like receptors. Ann Rev Immunol 2003; 21: 335-376.

40 Takeda K, Akira S. Toll-like receptors in innate immunity. Int Immunol 2005; 17: 1-14.

41 Kawai T, Akira S. The roles of TLRs, RLRs and NLRs in pathogen recognition. Int Immunol 2009; 21: 317-337.

42 Peng G, Guo Z, Kiniwa Y, Voo KS, Peng W, Fu T et al. Tolllike receptor 8-mediated reversal of CD4+ regulatory T cell function. Science 2005; 309: 1380-1384.

43 Rodriguez MM, Rowden G, Hackett J, Bakos I. Langerhans cells in the normal conjunctiva and peripheral cornea of selected species. Invest Ophthalmol Vis Sci 1981; 21: 759-765.

44 Gillette TE, Chandler JW, Greiner JV. Langerhans cells of the ocular surface. Ophthalmology 1982; 89: 700-711.

45 Whitsett CF, Stulting RD. The distribution of HLA antigens on human corneal tissue. Invest Ophthalmol Vis Sci 1984; 25: 519-524.

46 Williams KA, Ash JK, Coster DJ. Histocompatibility antigen and passenger cell content of normal and diseased human cornea. Transplantation 1985; 39: 265-269.

47 Brissette-Storkus CS, Reynolds SM, Lepisto AJ, Hendricks RL. Identification of a novel macrophage population in the normal mouse corneal stroma. Invest Ophthalmol Vis Sci 2002; 43: 2264-2271.

48 Hamrah P, Huq SO, Liu Y, Zhang Q, Dana MR. Corneal immunity is mediated by heterogeneous population of antigen-presenting cells. J Leukoc Biol 2003; 74: 172-178.

49 Knickelbein JE, Buela KA, Hendricks RL. Antigenpresenting cells are stratified within normal human corneas and are rapidly mobilized during ex vivo viral infection. Invest Ophthalmol Vis Sci 2014; 55: 1118-1123.

50 Hamrah P, Liu Y, Zhang Q, Dana MR. The corneal stroma is endowed with a significant number of resident dendritic cells. Invest Ophthalmol Vis Sci 2003; 44: 581-589.

51 Yamagami S, Ebihara N, Usui T, Yokoo S, Amano S. Bone marrow-derived cells in normal human corneal stroma. Arch Ophthalmol 2006; 124: 62-69.

52 Yamagami S, Usui T, Amano S, Ebihara N. Bone marrowderived cells in mouse and human cornea. Cornea 2005; 24: S71-S74.

53 Hamrah P, Liu Y, Zhang Q, Dana MR. Alterations in corneal stromal dendritic cell phenotype and distribution in inflammation. Arch Ophthalmol 2003; 121: 1132-1140.

54 Martinon F, Burns K, Tschopp J. The inflammasome: a molecular platform triggering activation of inflammatory caspases and processing of proIL-beta. Mol Cell 2002; 10: 417-426.

55 Schroder K, Tschopp J. The inflammasomes. Cell 2010; 140: 821-832.
56 Latz E, Xiao TS, Stutz A. Activation and regulation of the inflammasomes. Nat Rev Immunol 2013; 13: 397-411.

57 von Moltke J, Ayres JS, Kofoed EM, Chavarria-Smith J, Vance RE. Recognition of bacteria by inflammasomes. Annu Rev Immunol 2013; 31: 73-106.

58 Qiao Y, Wang P, Qi J, Zhang L, Gao C. TLR-induced NFkappaB activation regulates NLRP3 expression in murine macrophages. FEBS Lett 2012; 586: 1022-1026.

59 Kofoed EM, Vance RE. Innate immune recognition of bacterial ligands by NAIPs determines inflammasome specificity. Nature 2011; 477: 592-595.

60 Mariathasan S, Newton K, Monack DM, Vucic D, French DM, Lee WP et al. Differential activation of the inflammasome by caspase-1 adaptors ASC and Ipaf. Nature 2004; 430: 213-218.

61 Kayagaki N, Warming S, Lamkanfi M, Vande Walle L, Louie S, Dong J et al. Non-canonical inflammasome activation targets caspase-11. Nature 2011; 479: 117-121.

62 Meunier E, Dick MS, Dreier RF, Schurmann N, Kenzelmann Broz D, Warming $S$ et al. Caspase- 11 activation requires lysis of pathogen-containing vacuoles by IFN-induced GTPases. Nature 2014; 509: 366-370.

63 Said-Sadier N, Padilla E, Langsley G, Ojcius DM. Aspergillus fumigatus stimulates the NLRP3 inflammasome through a pathway requiring ROS production and the Syk tyrosine kinase. PLoS One 2010; 5: e10008.

64 Karthikeyan RS, Leal Jr SM, Prajna NV, Dharmalingam K, Geiser DM, Pearlman E et al. Expression of innate and adaptive immune mediators in human corneal tissue infected with Aspergillus or Fusarium. J Infect Dis 2011; 204: 942-950.

65 Zhao Y, Yang J, Shi J, Gong YN, Lu Q, Xu H et al. The NLRC4 inflammasome receptors for bacterial flagellin and type III secretion apparatus. Nature 2011; 477: 596-600.

66 McNeela EA, Burke A, Neill DR, Baxter C, Fernandes VE, Ferreira D et al. Pneumolysin activates the NLRP3 inflammasome and promotes proinflammatory cytokines independently of TLR4. PLoS Pathog 2010; 6: e1001191.

67 Karthikeyan RS, Priya JL, Leal Jr SM, Toska J, Rietsch A, Prajna V et al. Host response and bacterial virulence factor expression in Pseudomonas aeruginosa and Streptococcus pneumoniae corneal ulcers. PloS One 2013; 8: e64867.

68 Mariathasan S, Weiss DS, Newton K, McBride J, O'Rourke $\mathrm{K}$, Roose-Girma $\mathrm{M}$ et al. Cryopyrin activates the inflammasome in response to toxins and ATP. Nature 2006; 440: 228-232.

69 Gombault A, Baron L, Couillin I. ATP release and purinergic signaling in NLRP3 inflammasome activation. Front Immunol 2012; 3: 414.

70 Zhou R, Yazdi AS, Menu P, Tschopp J. A role for mitochondria in NLRP3 inflammasome activation. Nature 2011; 469: 221-225.

71 Stapleton F, Dart JKG, Seal DV, Matheson M. Epidemiology of Pseudomonas aeruginosa keratitis in contact lens wearers. Epidemiol Infect 1995; 114: 395-402.

72 Sy A, Srinivasan M, Mascarenhas J, Lalitha P, Rajaraman R, Ravindran $\mathrm{M}$ et al. Pseudomonas aeruginosa keratitis: outcomes and response to corticosteroid treatment. Invest Ophthalmol Vis Sci 2012; 53: 267-272.

73 Fleiszig SM, Evans DJ, Do N, Vallas V, Shin S, Mostov KE. Epithelial cell polarity affects susceptibility to Pseudomonas aeruginosa invasion and cytotoxicity. Infect Immun 1997; 65: 2861-2867.

74 Mun JJ, Tam C, Kowbel D, Hawgood S, Barnett MJ, Evans DJ et al. Clearance of Pseudomonas aeruginosa from a healthy 
ocular surface involves surfactant protein $\mathrm{D}$ and is compromised by bacterial elastase in a murine nullinfection model. Infect Immun 2009; 77: 2392-2398.

75 Selinger DS, Selinger RC, Reed WP. Resistance to infection of the external eye: the role of tears. Surv Ophthalmol 1979; 24: 33-38.

76 Flanagan JL, Willcox MD. Role of lactoferrin in the tear film. Biochimie 2009; 91: 35-43.

77 Fleiszig SM, Kwong MS, Evans DJ. Modification of Pseudomonas aeruginosa interactions with corneal epithelial cells by human tear fluid. Infect Immun 2003 ; 71: 3866-3874

78 Kwong MS, Evans DJ, Ni M, Cowell BA, Fleiszig SM. Human tear fluid protects against Pseudomonas aeruginosa keratitis in a murine experimental model. Infect Immun 2007; 75: 2325-2332.

79 Sun Y, Karmakar M, Roy S, Ramadan RT, Williams SR, Howell $S$ et al. TLR4 and TLR5 on corneal macrophages regulate Pseudomonas aeruginosa keratitis by signaling through MyD88-dependent and -independent pathways. J Immunol 2010; 185: 4272-4283.

80 Takeda K, Akira S. TLR signaling pathways. Semin Immunol 2007; 19: 24-32.

81 Shimazu R, Akashi S, Ogata H, Nagai Y, Fukudome K, Miyake $\mathrm{K}$ et al. MD-2, a molecule that confers lipopolysaccharide responsiveness on Toll-like receptor 4 . J Exp Med 1999; 189: 1777-1782.

82 Miyake K. Roles for accessory molecules in microbial recognition by Toll-like receptors. J Endotoxin Res 2006; 12: 195-204.

83 Chinnery HR, Carlson EC, Sun Y, Lin M, Burnett SH, Perez VL et al. Bone marrow chimeras and $c$-fms conditional ablation (Mafia) mice reveal an essential role for resident myeloid cells in lipopolysaccharide/TLR4-induced corneal inflammation. I Immunol 2009; 182: 2738-2744.

84 Roy S, Sun Y, Pearlman E. Interferon-gamma-induced MD-2 protein expression and lipopolysaccharide (LPS) responsiveness in corneal epithelial cells is mediated by Janus tyrosine kinase-2 activation and direct binding of STAT1 protein to the MD-2 promoter. J Biol Chem 2011; 286: 23753-23762

85 Hazlett LD, Li Q, Liu J, McClellan S, Du W, Barrett RP. NKT cells are critical to initiate an inflammatory response after Pseudomonas aeruginosa ocular infection in susceptible mice. J Immunol 2007; 179: 1138-1146.

86 Huang X, Du W, McClellan SA, Barrett RP, Hazlett LD. TLR4 is required for host resistance in Pseudomonas aeruginosa keratitis. Invest Ophthalmol Vis Sci 2006; 47: 4910-4916.

87 Yamamoto M, Sato S, Hemmi H, Hoshino K, Kaisho T, Sanjo $\mathrm{H}$ et al. Role of adaptor TRIF in the MyD88independent Toll-like receptor signaling pathway. Science 2003; 301: 640-643.

88 Oganesyan G, Saha SK, Guo B, He JQ, Shahangian A, Zarnegar B et al. Critical role of TRAF3 in the Toll-like receptor-dependent and -independent antiviral response. Nature 2006; 439: 208-211.

89 Lee MS, Kim YJ. Signaling pathways downstream of pattern-recognition receptors and their cross talk. Ann Rev Biochem 2007; 76: 447-480.

90 Lichtinger A, Yeung SN, Kim P, Amiran MD, Iovieno A Elbaz U et al. Shifting trends in bacterial keratitis in Toronto: an 11- year review. Ophthalmology 2012; 119: 1785-1790.
91 Kaliamurthy J, Kalavathy CM, Parmar P, Jesudasan CAN, Thomas PA. Spectrum of bacterial keratitis at a tertiary eye care centre in India. Biomed Res Int 2013; 2013: 181564.

92 Orlans HO, Hornby SJ, Bowler IC. In vitro antibiotic susceptibility patterns of bacterial keratitis isolates in Oxford, UK: a 10-year review. Eye 2011; 25: 489-493.

93 Moreau JM, Girgis DO, Hume EBH, Dajcs JJ, Austin MS, O'Callaghan RJ. Phospholipase A2 in rabbit tears: a host defense against Staphylococcus aureus. Invest Ophthalmol Vis Sci 2001; 42: 2347-2354.

94 Heimer SR, Yamada A, Russell H, Gilmore M. Response of corneal epithelial cells to Staphylococcus aureus. Virulence 2010; 1: 223-235.

95 Li Q, Kumar A, Gui JF, Yu FS. Staphylococcus aureus lipoproteins trigger human corneal epithelial innate response through toll-like receptor-2. Microb Pathog 2008; 44: 426-434.

96 Sun Y, Hise AG, Kalsow CM, Pearlman E. Staphylococcus aureus-induced corneal inflammation is dependent on tolllike receptor 2 and myeloid differentiation factor 88 . Infect Immun 2006; 74: 5325-5332.

97 Kumar A, Zhang Z, Yu FS. Innate immune response of corneal epithelial cells to Staphylococcus aureus infection: role of peptidoglycan in stimulating proinflammatory cytokine secretion. Invest Ophthalmol Vis Sci 2004; 45: 3513-3522.

98 Kumar A, Tassopoulos AM, Li Q, Yu FS. Staphylococcus aureus protein $\mathrm{A}$ induced inflammatory response in human corneal epithelial cells. Biochem Biophys Res Commun 2007; 354: 955-961.

99 Kumar A, Zhang J, Yu FS. Toll-like receptor 2-mediated expression of $\beta$-defensin- 2 in human corneal epithelial cells. Microbes Infect 2006; 8: 380-389.

100 Adhikary G, Sun Y, Pearlman E. C-Jun $\mathrm{NH}_{2}$ terminal kinase (JNK) is an essential mediator of Toll-like receptor 2induced corneal inflammation. J Leukoc Biol 2008; 83: 991-997.

101 Bartlett A, Turk J, Ngu JL, Mackenzie CD, Fuglsang H, Anderson J. Variations in delayed hypersensitivity in dermal onchocerciasis. Trans R Soc Trop Med Hyg 1978; 72: 372-377.

102 Ali MM, Baraka OZ, AbdelRahman SI, Sulaiman SM, Williams JF, Homeida MM et al. Immune responses directed against microfilariae correlate with severity of clinical onchodermatitis and treatment history. J Infect Dis 2003; 187: 714-717.

103 Chakravarti B, Lass JH, Diaconu E, Bardenstein DS, Roy CE, Herring TA et al. Immune-mediated Onchocerca volvulus sclerosing keratitis in the mouse. Exp Eye Res 1993; 57: 21-27.

104 Donnelly JJ, Rockey JH, Bianco AE, Soulsby EJ. Ocular immunopathologic findings of experimental onchocerciasis. Arch Ophthalmol 1984; 102: 628-634.

105 Timmann C, Abraha RS, Hamelmann C, Buttner DW, Lepping B, Marfo Y et al. Cutaneous pathology in onchocerciasis associated with pronounced systemic T-helper 2-type responses to Onchocerca volvulus. Br J Dermatol 2003; 149: 782-787.

106 Pearlman E, Lass JH, Bardenstein DS, Kopf M, Hazlett FE, Diaconu $\mathrm{E}$ et al. Interleukin 4 and T helper type 2 cells are required for development of experimental onchocercal keratitis (river blindness). J Exp Med 1995; 182: 931-940.

107 Hall L, Lass RJ, Diaconu E, Strine ER, Pearlman E. An essential role for antibody in neutrophil and eosinophil 
recruitment to the cornea: $\mathrm{B}$ cell deficient $(\mu \mathrm{MT})$ mice fail to develop Th2-dependent, helminth-mediated keratitis. J Immunol 1999; 163: 4970-4975.

108 Kozek WJ, Marroquin HF. Intracytoplasmic bacteria in Onchocerca volvulus. Am J Trop Med Hyg 1977; 26: 663-678.

109 Taylor MJ, Bandi C, Hoerauf A. Wolbachia bacterial endosymbionts of filarial nematodes. Adv Parasitol 2005; 60: 245-284.

110 Hise AG, Daehnel K, Gillette-Ferguson I, Cho E, McGarry $\mathrm{HF}$, Taylor MJ et al. Innate immune responses to endosymbiotic Wolbachia bacteria in Brugia malayi and Onchocerca volvulus are dependent on TLR2, TLR6, MyD88, and Mal, but not TLR4, TRIF, or TRAM. J Immunol 2007; 178: 1068-1076.

111 Pearlman E, Hall LR. Immune mechanisms in Onchocerca volvulus-mediated corneal disease (river blindness). Parasite Immunol 2000; 22: 625-631.

112 Turner JD, Langley RS, Johnston KL, Gentil K, Ford L, Wu $\mathrm{B}$ et al. Wolbachia lipoprotein stimulates innate and adaptive immunity through Toll-like receptors 2 and 6 to induce disease manifestations of filariasis. J Biol Chem 2009; 284: 22364-22378.

113 Hall LR, Diaconu E, Patel R, Pearlman E. CXC chemokine receptor 2 but not $\mathrm{C}-\mathrm{C}$ chemokine receptor 1 expression is essential for neutrophil recruitment to the cornea in helminth-mediated keratitis (river blindness). J Immunol 2001; 166: 4035-4041.

114 Kaifi JT, Diaconu E, Pearlman E. Distinct roles for PECAM-1, ICAM-1, and VCAM-1 in recruitment of neutrophils and eosinophils to the cornea in ocular onchocerciasis (river blindness). J Immunol 2001; 166: 6795-6801.

115 Hall LR, Kaifi JT, Diaconu E, Pearlman E. CD4 ${ }^{+}$depletion selectively inhibits eosinophil recruitment to the cornea and abrogates Onchocerca volvulus keratitis (river blindness). Infect Immun 2000; 68: 5459-5461.

116 Pearlman E, Hall LR, Higgins AW, Bardenstein DS, Diaconu E, Hazlett FE et al. The role of eosinophils and neutrophils in helminth-induced keratitis. Invest Ophthalmol Vis Sci 1998; 39: 1176-1182.

117 Srinivasan M. Fungal keratitis. Curr Opin Ophthalmol 2004; 15: 321-327.

118 Prajna NV, Srinivasan M, Lalitha P, Krishnan T, Rajaraman R, Ravindran $\mathrm{M}$ et al. Differences in clinical outcomes in keratitis due to fungus and bacteria. JAMA Ophthalmol 2013; 131: 1088-1089.

119 Yildiz EH, Airiani S, Hammersmith KM, Rapuano CJ, Laibson PR, Virdi AS et al. Trends in contact lens-related corneal ulcers at a tertiary referral center. Cornea 2012; 31: 1097-1102.

120 Liesegang TJ, Forster RK. Spectrum of microbial keratitis in south Florida. Am J Ophthalmol 1980; 90: 38-47.

121 Pachigolla G, Blomquist P, Cavanagh HD. Microbial keratitis pathogens and antibiotic susceptibilities: a 5-year review of cases at an urban county hospital in north Texas. Eye Contact Lens 2007; 33: 45-49.

122 Xie L, Zhong W, Shi W, Sun S. Spectrum of fungal keratitis in north China. Ophthalmology 2006; 113: 1943-1948.

123 Bharathi MJ, Ramakrishnan R, Meenakshi R, Padmavathy S, Shivakumar C, Srinivasan M. Microbial keratitis in South India: influence of risk factors, climate, and geographical variation. Ophthalmic Epidemiol 2007; 14: 61-69.

124 Carrion S de J, Leal Jr SM, Ghannoum MA, Aimanianda V, Latgé JP, Pearlman E. The RodA hydrophobin on
Aspergillus fumigatus spores masks dectin-1- and dectin- 2dependent responses and enhances fungal survival in vivo. J Immunol 2013; 191: 2581-2588.

125 Leal Jr SM, Cowden S, Hsia YC, Ghannoum MA, Momany M, Pearlman E. Distinct roles for Dectin-1 and TLR4 in the pathogenesis of Aspergillus fumigatus keratitis. PLoS Pathog 2010; 6: e1000976.

126 Tarabishy AB, Aldabagh B, Sun Y, Imamura Y, Mukherjee $\mathrm{PK}$, Lass JH et al. MyD88 regulation of Fusarium keratitis is dependent on TLR4 and IL-1R1 but not TLR2. J Immunol 2008; 181: 593-600.

127 Taylor PR, Leal Jr SM, Sun Y, Pearlman E. Aspergillus and Fusarium corneal infections are regulated by Th17 cells and IL-17 producting neutrophils. J Immunol 2014; 192: 3319-3327.

128 Farooq AV, Shukla D. Herpes simplex epithelial and stromal keratitis: an epidemiologic update. Surv Ophthalmol 2012; 57: 448-462.

129 Spear PG. Herpes simplex virus: receptors and ligands for cell entry. Cell Microbiol 2004; 6: 401-410.

130 Herold BC, WuDunn D, Soltys N, Spear PG. Glycoprotein $C$ of herpes simplex virus type 1 plays a principal role in the adsorption of virus to cells and in infectivity. J Virol 1991; 65: 1090-1098.

131 Subramanian RP, Geraghty RJ. Herpes simplex virus type 1 mediates fusion through a hemifusion intermediate by sequential activity of glycoproteins D, H, L, and B. Proc Natl Acad Sci USA 2007; 104: 2903-2908.

132 Montgomery RI, Warner MS, Lum BJ, Spear PG. Herpes simplex virus-1 entry into cells mediated by a novel member of the TNF/NGF receptor family. Cell 1996; 87: 427-436.

133 Geraghty RJ, Krummenacher C, Cohen GH, Eisenberg RJ, Spear PG. Entry of alphaherpesviruses mediated by poliovirus receptor-related protein 1 and poliovirus receptor. Science 1998; 280: 1618-1620.

134 Shukla D, Liu J, Blaiklock P, Shworak NW, Bai X, Esko JD et al. A novel role for 3-O-sulfated heparan sulfate in herpes simplex virus 1 entry. Cell 1999; 99: 13-22.

135 Satoh T, Arii J, Suenaga T, Wang J, Kogure A, Uehori J et al. PILRalpha is a herpes simplex virus-1 entry coreceptor that associates with glycoprotein B. Cell 2008; 132: 935-944.

136 Shukla ND, Tiwari V, Valyi-Nagy T. Nectin-1-specific entry of herpes simplex virus 1 is sufficient for infection of the cornea and viral spread to the trigeminal ganglia. Mol Vis 2012; 18: 2711-2716.

137 Kolb AW, Ané C, Brandt CR. Using HSV-1 genome phylogenetics to track past human migrations. PLoS One 2013; 8: e76267.

138 Norberg P, Bergström T, Rekabdar E, Lindh M, Liljeqvist JA. Phylogenetic analysis of clinical herpes simplex virus type 1 isolates identified three genetic groups and recombinant viruses. J Virol 2004; 78: 10755-10764.

139 Kurt-Jones EA, Chan M, Zhou S, Wang J, Reed G, Bronson $\mathrm{R}$ et al. Herpes simplex virus 1 interaction with Toll-like receptor 2 contributes to lethal encephalitis. Proc Natl Acad Sci USA 2004; 101: 1315-1320.

140 Sarangi PP, Kim B, Kurt-Jones E, Rouse BT. Innate recognition network driving herpes simplex virus-induced corneal immunopathology: role of the toll pathway in early inflammatory events in stromal keratitis. J Virol 2007; 81: 11128-11138. 
141 Krug A, Luker GD, Barchet W, Leib DA, Akira S, Colonna M. Herpes simplex virus type 1 activates murine natural interferon-producing cells through toll-like receptor 9. Blood 2004; 103: 1433-1437.

142 Lundberg P, Welander P, Han X, Cantin E. Herpes simplex virus type 1 DNA Is immunostimulatory in vitro and in vivo. J Virol 2003; 77: 11158-11169.

143 Kariko K, Ni H, Capodici J, Lamphier M, Weissman D. mRNA is an endogenous ligand for Toll-like receptor 3. J Biol Chem 2004; 279: 12542-12550.

144 Zhang SY, Jouanguy E, Ugolini S, Smahi A, Elain G, Romero $\mathrm{P}$ et al. TLR3 deficiency in patients with herpes simplex encephalitis. Science 2007; 317: 1522-1527.

145 Li H, Zhang J, Kumar A, Zheng M, Atherton SS, Yu FS. Herpes simplex virus 1 infection induces the expression of proinflammatory cytokines, interferons and TLR7 in human corneal epithelial cells. Immunology 2006; 117: 167-176.

146 Takeda S, Miyazaki D, Sasaki S, Yamamoto Y, Terasaka Y, Yakura $\mathrm{K}$ et al. Roles played by Toll-like receptor 9 in corneal endothelial cells after herpes simplex virus type 1 infection. Invest Ophthalmol Vis Sci 2011; 52: 6729-6736.

147 Alexopoulou L, Holt AC, Medzhitov R, Flavell RA. Recognition of double-stranded RNA and activation of NFkappaB by Toll-like receptor 3. Nature 2001; 413: 732-738.

148 Oshiumi H, Matsumoto M, Funami K, Akazawa T, Seya T. TICAM-1, an adaptor molecule that participates in Toll-like receptor 3-mediated interferon-beta induction. Nat Immunol 2003; 4: 161-167.

149 Yamamoto M, Sato S, Mori K, Hoshino K, Takeuchi O, Takeda K et al. Cutting edge: a novel Toll/IL-1 receptor domain-containing adapter that preferentially activates the IFN-beta promoter in the Toll-like receptor signaling. J Immunol 2002; 169: 6668-6672.

150 Kumar A, Zhang J, Yu FS. Toll-like receptor 3 aconist poly (I:C)-induced antiviral response in human corneal epithelial cells. Immunology 2006; 117: 11-21.

151 Fitzgerald KA, McWhirter SM, Faia KL, Rowe DC, Latz E, Golenbock DT et al. IKKepsilon and TBK1 are essential components of the IRF3 signaling pathway. Nat Immunol 2003; 4: 491-496.

152 Honda K, Yanai H, Negishi H, Asagiri M, Sato M, Mizutani T et al. IRF-7 is the master regulator of type-I interferon-dependent immune responses. Nature 2005; 434: 772-777.

153 Honda K, Yanai H, Mizutani T, Negishi H, Shimada N, Suzuki $\mathrm{N}$ et al. Role of a transductional-transcriptional processor complex involving MyD88 and IRF-7 in Toll-like receptor signaling. Proc Natl Acad Sci USA 2004; 101: 15416-15421.

154 Rowe St AM, Leger AJ, Jeon S, Dhaliwal DK, Knickelbein JE, Hendricks RL. Herpes keratitis. Prog Retin Eye Res 2013; 32: 88-101.

155 Roizman B, Zhou G, Du T. Checkpoints in productive and latent infections with herpes simplex virus 1 : conceptualization of the issues. J Neurovirol 2011; 17: 512-517.

156 Khanna KM, Bonneau RH, Kinchington PR, Hendricks RL. Herpes simplex virus-specific memory $\mathrm{CD} 8^{+} \mathrm{T}$ cells are selectively activated and retained in latently infected sensory ganglia. Immunity 2003; 18: 593-603.

157 West DM, Del Rosso CR, Yin XT, Stuart PM. CXCL1 but not IL-6 is required for recurrent herpetic stromal keratitis. J Immunol 2014; 192: 1762-1767.
158 Keadle TL, Morris JL, Pepose JS, Stuart PM. CD4(+) and CD8(+) cells are key participants in the development of recurrent herpetic stromal keratitis in mice. Microb Pathog 2002; 32: 255-262.

159 Stuart PM, Morris JE, Sidhu M, Keadle TL. CCL3 protects mice from corneal pathology during recurrent HSV-1 infection. Front Biosci 2008; 13: 4407-4415.

160 Aksozek A, McClellan K, Howard K, Niederkorn JY, Alizadeh H. Resistance of Acanthamoeba castellanii cysts to physical, chemical, and radiological conditions. J Parasitol 2002; 88: 621-623.

161 Leher H, Kinoshita K, Alizadeh H, Zaragoza FL, He Y, Niederkorn JY. Impact of oral immunization with Acanthamoeba antigens on parasite adhesion and corneal infection. Invest Ophthalmol Vis Sci 1998; 39: 2337-2343.

162 Alizadeh H, He Y, McCulley JP, Ma D, Stewart GL, Via M et al. Successful immunization against Acanthamoeba keratitis in a pig model. Cornea 1995; 14: 180-186.

163 van Klink F, Leher H, Jager MJ, Alizadeh H, Taylor W, Niederkorn JY. Systemic immune response to Acanthamoeba keratitis in the Chinese hamster. Ocul Immunol Inflamm 1997; 5: 235-244.

164 Niederkorn JY. The role of the innate and adaptive immune responses in Acanthamoeba keratitis. Arch Immunol Ther Exp (Warsz) 2002; 50: 53-59.

165 Alizadeh H, Apte S, El-Agha MS, Li L, Hurt M, Howard K et al. Tear IgA and serum IgG antibodies against Acanthamoeba in patients with Acanthamoeba keratitis. Cornea 2001; 20: 622-627.

166 Leher HF, Alizadeh H, Taylor WM, Shea AS, Silvany RS, van Klink $\mathrm{F}$ et al. Role of mucosal IgA in the resistance to Acanthamoeba keratitis. Invest Ophthalmol Vis Sci 1998; 39: 2666-2673.

167 Stewart GL, Kim I, Shupe K, Alizadeh H, Silvany R, McCulley JP et al. Chemotactic response of macrophages to Acanthamoeba castellanii antigen and antibody-dependent macrophage-mediated killing of the parasite. J Parasitol 1992; 78: 849-855.

168 Said NA, Shoeir AT, Panjwani N, Garate M, Cao Z. Local and systemic humoral immune response during acute and chronic Acanthamoeba keratitis in rabbits. Curr Eye Res 2004; 29: 429-439.

169 Stewart GL, Shupe K, Kim I, Silvany RE, Alizadeh H, McCulley JP et al. Antibody-dependent neutrophilmediated killing of Acanthamoeba castellanii. Int J Parasitol 1994; 24: 739-742.

170 Garate M, Cao Z, Bateman E, Panjwani N. Cloning and characterization of a novel mannose-binding protein of Acanthamoeba. J Biol Chem 2004; 279: 29849-29856.

171 Yang Z, Cao Z, Panjwani N. Pathogenesis of Acanthamoeba keratitis: carbohydrate-mediated host-parasite interactions. Infect Immun 1997; 65: 439-445.

172 Hurt M, Neelam S, Niederkorn J, Alizadeh H. Pathogenic Acanthamoeba spp. secrete a mannose-induced cytolytic protein that correlates with the ability to cause disease. Infect Immun 2003; 71: 6243-6255.

173 Leher HF, Silvany RE, Alizadeh H, Huang J, Niederkorn JY. Mannose induces the release of cytopathic factors from Acanthamoeba castellanii. Infect Immun 1998; 66: 5-10.

174 Ren M, Gao L, Wu X. TLR4: the receptor bridging Acanthamoeba challenge and intracellular inflammatory responses in human corneal cell lines. Immunol Cell Biol 2010; 88: 529-536. 
175 Alizadeh H, Tripathi T, Abdi M, Smith AD. Pathogenic strains of Acanthamoeba are recognized by TLR4 and initiated inflammatory responses in the cornea. PLoS One 2014; 9: e92375.

176 Alizadeh H, Neelam S, Niederkorn JY. Role of activated macrophages in Acanthamoeba keratitis. J Parasitol 2007; 93 1114-1120.

177 van Klink F, Taylor WM, Alizadeh H, Jager MJ, van Rooijen $\mathrm{N}$, Niederkorn JY. The role of macrophages in Acanthamoeba keratitis. Invest Ophthalmol Vis Sci 1996; 37: 1271-1281.

178 Hurt M, Apte S, Leher H, Howard K, Niederkorn J, Alizadeh H. Exacerbation of Acanthamoeba keratitis in animals treated with anti-macrophage inflammatory protein 2 or antineutrophil antibodies. Infect Immun 2001; 69: 2988-2995.

179 Hurt M, Proy V, Niederkorn JY, Alizadeh. H. The interaction of Acanthamoeba castellanii cysts with macrophages and neutrophils. J Parasitol 2003; 89: 565-572.

180 McClellan K, Howard K, Niederkorn JY, Alizadeh H. Effect of steroids on Acanthamoeba cysts and trophozoites. Invest Ophthalmol Vis Sci 2001; 42: 2885-2893.

181 Iovieno A, Ledee DR, Miller D, Alfonso EC. Detection of bacterial endosymbionts in clinical Acanthamoeba isolates. Ophthalmology 2010; 117: 445-452.

182 Ponder E, Kennedy WP. On the act of blinking. Experimental Physiology 1927; 18: 89-110.

183 Blount WP. Studies of the movements of the eyelids of animals: blinking. Experimental Physiology 1927; 18: 111-125.

184 Schechter JE, Warren DW, Mircheff AK. A lacrimal gland is a lacrimal gland, but rodent's and rabbit's are not human. Ocul Surf 2010; 8: 111-134.

185 Hayashi S, Osawa T, Tohyama K. Comparative observations on corneas, with special reference to Bowman's layer and Descemet's membrane in mammals and amphibians. J Morphol 2002; 254: 247-258.

186 Hayes S, Boote C, Lewis J, Sheppard J, Abahussin M, Quantock AJ et al. Comparative study of fibrillar collagen arrangement in the corneas of primates and other mammals. Anat Rec (Hoboken) 2007; 290: 1542-1550.

187 Henriksson JT, McDermott AM, Bergmanson JP. Dimensions and morphology of the cornea in three strains of mice. Invest Ophthalmol Vis Sci 2009; 50: 3648-3654.

188 Tenthorey JL, Kofoed EM, Daugherty MD, Malik HS, Vance RE. Molecular basis for specific recognition of bacterial ligands by NAIP/NLRC4 inflammasomes. Mol Cell 2014; 54: 17-29.

189 Mcllwain DR, Berger T, Mak TW. Caspase functions in cell death and disease. Cold Spring Harb Perspect Biol 2013; 5: a008656.

190 Matsumoto K, Kosuke I, Tanihara H. Role of cytokines and chemokines in pseudomonal keratitis. Cornea 2005; 24: S43-S49.

191 Royle L, Matthews E, Corfield A, Berry M, Rudd PM, Dwek RA et al. Glycan structures of ocular surface mucins in man, rabbit and dog display species differences. Glycoconj J 2008; 25: 763-773.

192 Kupferman A, Leibowitz HM. Quantitation of bacterial infection and antibiotic effect in the cornea. Arch Ophthal 1976; 94: 1981-1984.

193 Gerke JR, Magliocco MV. Experimental Pseudomonas aeruginosa infection of the mouse cornea. Infect Immu 1971; 3: 209-216.
194 Kessler E, Mondino BJ, Brown SI. The corneal response to Pseudomonas aeruginosa: histopathological and enzymatic characterization. Invest Ophthalmol Vis Sci 1977; 16: 116-125.

195 Dannelly KH, Liu Y, Ghosh SK. Pseudomonas aeruginosa corneal infection affects cholinergic enzymes in rat lacrimal gland. Arch Microbiol 2001; 177: 47-53.

196 Johnson AC, Heinzel FP, Diaconu E, Sun Y, Hise AG, Golenbock D et al. Activation of toll-like receptor (TLR)2, TLR4, and TLR9 in the mammalian cornea induces MyD88dependent corneal inflammation. Invest Ophthalmol Vis Sci 2005; 46: 589-595.

197 Frucht-Pery J, Golan G, Hemo I, Zauberman H, Shapiro M. Efficacy of topical gentamicin treatment after 193-nm photorefractive keratectomy in an experimental Pseudomonas keratitis model. Graefes Arch Clin Exp Ophthalmol 1995; 233: 532-534.

198 Szliter E, Barrett RP, Gabriel MM, Zhang Y, Hazlett LD. Pseudomonas aeruginosa-induced inflammation in the rat extended-wear contact lens model. Eye Contact Lens 2006; 32: 12-18.

199 Srinivasan M, Mascarenhas J, Rajaraman R, Ravindran M, Lalitha P, Ray KJ et al.Steroids for Corneal Ulcers Trial Group. Visual recovery in treated bacterial keratitis. Ophthalmology 2014; 121: 1310-1311.

200 Hara Y, Shiraishi A, Kobayashi T, Kadota Y, Shirakata Y, Hashimoto $\mathrm{K}$ et al. Alteration of TLR3 pathways by glucocorticoids may be responsible for immunosusceptibility of human corneal epithelial cells to viral infections. Mol Vis 2009; 15: 937-948.

201 Srinivasan M, Mascarenhas J, Rajaraman R, Ravindran M, Lalitha P, O'Brien KS et al. Steroids for Corneal Ulcers Trial Group. The steroids for corneal ulcers trial (SCUT): secondary 12-month clinical outcomes of a randomized controlled trial. Am J Ophthalmol 2014; 157: 327-333.

202 Srinivasan M, Mascarenhas J, Rajaraman R, Ravindran M, Lalitha P, Glidden DV et al. Steroids for Corneal Ulcers Trial Group. Corticosteroids for bacterial keratitis: the Steroids for Corneal Ulcers Trial (SCUT). Arch Ophthalmol 2012; 130: 143-150.

203 Alekseev O, Donovan K, Azizkhan-Clifford J. Inhibition of ataxia telangiectasia mutated (ATM) kinase suppresses herpes simplex virus type 1 (HSV-1) keratitis. Invest Ophthalmol Vis Sci 2014; 55: 706-715.

204 Caballero A, Foletti D, Bierdeman M, Tang A, Arana A, Hasa-Moreno A et al. Effectiveness of alpha-toxin Fab monoclonal antibody therapy in limiting the pathology of Staphylococcus aureus keratitis. Ocul Immunol Inflamm 2014; 9: 1-7.

205 Suzuki T. A new target for Staphylococcus aureus associated with keratitis. Cornea 2011; 30: S34-S40.

206 Chen K, Wu Y, Zhu M, Deng Q, Nie X, Li M et al. Lithium chloride promotes host resistance against Pseudomonas aeruginosa keratitis. Mol Vis 2013; 19: 1502-1514.

207 Thakur A, Barrett RP, Hobden JA, Hazlett LD. Caspase-1 inhibitor reduces severity of Pseudomonas aeruginosa keratitis in mice. Invest Ophthalmol Vis Sci 2004; 45: 3177-3184.

208 Zhou Z, Wu M, Barrett RP, McClellan SA, Zhang Y, Hazlett LD. Role of the Fas pathway in Pseudomonas aeruginosa keratitis. Invest Ophthalmol Vis Sci 2010; 51: 2537-2547.

209 Sun M, Zhu M, Chen K, Nie X, Deng Q, Hazlett LD et al. TREM-2 promotes host resistance against Pseudomonas aeruginosa infection by suppressing corneal inflammation via a PI3K/Akt signaling pathway. Invest Ophthalmol Vis Sci 2013; 54: 3451-3462. 
210 Guo H, Gao J, Wu X. Toll-like receptor 2 siRNA suppresses corneal inflammation and attenuates Aspergillus fumigatus keratitis in rats. Immunol Cell Biol 2012; 90: 352-357.

211 Oh JY, Choi H, Lee RH, Roddy GW, Ylöstalo JH, Wawrousek E et al. Identification of the HSPB4/TLR2/NF$\kappa \mathrm{B}$ axis in macrophage as a therapeutic target for sterile inflammation of the cornea. EMBO Mol Med 2012; 4: 435-448.

212 Hoerauf A, Volkmann L, Hamelmann C, Adjei O, Autenrieth IB, Fleischer B et al. Endosymbiotic bacteria in worms as targets for a novel chemotherapy in filariasis. Lancet 2000; 355: 1242-1243.

213 Hoerauf A, Specht S, Büttner M, Pfarr K, Mand S, Fimmers R et al. Wolbachia endobacteria depletion by doxycycline as antifilarial therapy has macrofilaricidal activity in onchocerciasis: a randomized placebo-controlled study. Med Microbiol Immunol 2008; 197: 295-311.

214 Turner JD, Tendongfor N, Esum M, Johnston KL, Langley RS, Ford L et al. Macrofilaricidal activity after doxycycline only treatment of Onchocerca volvulus in an area of Loa loa co-endemicity: a randomized controlled trial. PLoS Negl Trop Dis 2010; 4: e660.

215 Tsatsos M, Hawkin PN, Hossain P. Corneal response to canakinumab in cryopyrin associated periodic fever syndrome. Br J Ophthalmol 2013; 97: 1081-1082.

216 Terrada C, Neven B, Boddaert N, Souied EH, Prieur AM, Quartier $\mathrm{P}$ et al. Ocular modifications in a young girl with cryopyrin-associated periodic syndromes responding to interleukin-1 receptor antagonist anakira. J Ophthalmic Inflamm Infect 2011; 1: 133-136.

217 Alio JL, Abbouda A, Valle DD, Benitez del Castillo JM, Gegundez Fernandez JA. 1364 Corneal cross linking and infectious keratitis: a systematic review with a meta-1365 analysis of reported cases. J Ophthalmic Inflamm Infect 2013; 3: 47-54.

218 Huang X, Barrett RP, McClellan SA, Hazlett LD. Silencing Toll-like receptor-9 in Pseudomonas aeruginosa keratitis. Invest Ophthalmol Vis Sci 2005; 46: 4209-4216. 